\title{
CONSTRUCTION OF FOREWARNING RISK INDEX SYSTEMS OF VENTURE CAPITAL BASED ON ARTIFICIAL NEURAL NETWORK
}

\author{
Guozheng Zhang, Yun Chen, Dengfeng Hu \\ School of Public Economy Administration, Shanghai University of Finance \& Economics, \\ P.R.china, 200433,Email:guozhengzhang@gmail.com
}

\begin{abstract}
The risk evaluation is a very important step of decision process of venture capital. This article constructs forewarning risk index systems of venture capital, and applies Artificial Neural Network (ANN) to forecast the latent risk level of venture capital. Empirical analysis indicates that this model could predict the latent risk of venture capital very well.
\end{abstract}

Key words: Artificial neural network, Forewarning risk index system, Venture capital

\section{INTRODUCTION}

Venture capital is a kind of equity capital that the professional venture capitalist puts into venture enterprises [1,2]. Presently, Risk forewarning system based on neural network has been applied in many fields such as Credit risk evaluation, Project management and so on $[7,8,6,10]$. Kuldeep Kumar, John D Hayneshave provided that the ANN is better than statistical techniques on forecasting credit risk level because risk has non-linear relationship with its affected factors[9]. None of current literatures about venture capital has constructed forewarn system based on neural network to forecast the investment risk. There are two questions: (1) How to construct forewarning risk index systems; (2) How to apply neural network to predict risk level? The evaluation target is very complicated. It is a multifactor

The project is supported by the Shanghai Shuguang Project of China under the grant No: 05SG38

Please use the following format when citing this chapter:

Zhang, Guozheng, Chen, Yun, Hu, Dengfeng, 2006, in International Federation for Information Processing (IFIP), Volume 207, Knowledge Enterprise: Intelligent Strategies In Product Design, Manufacturing, and Management, eds. K. Wang, Kovacs G., Wozny M., Fang M., (Boston: Springer), pp. 812-817. 
comprehensive decision question [3]. This article effectively evaluates the risk constructing appropriate forewarning risk index system and effectively applying artificial neural network technology.

\section{FOREWARNING RISK INDEX SYSTEM OF VENTURE CAPITAL}

\subsection{Contents of forewarning risk index system}

The research of venture capital decision has interested people since the 1980s abroad. Tyebjee and Bruno has listed the evaluation index from qualitative angle, using questionnaire investigation and factor analytic approach to construct the U.S.A evaluation models of venture capital at first[1]. Vance H Fried and Robert D Hisrich extended this model and indicated that such as managerial ability and resistance ability of environment threaten, etc. has a great influence on expected risk of venture capital[3]. While carrying on venture capital decision, venture capitalist must consider every factor impacting on risk synthetically $[2,4]$. According to the characteristic of operating venture capital, this article carries on systemic analysis on every factor which forms the risk and attempts to construct a forewarning risk index system including managerial ability, resistive ability to environmental threat, market risk, technological risk, production risk, withdraw channel, etc. 6 first class index and relevant 36 sub index.(Table.1)

Table 1. Forewarning risk index system of venture capital

\begin{tabular}{|c|c|c|c|}
\hline \multicolumn{4}{|c|}{ Forewarning Index Systems of the Venture Enterprise $(U)$} \\
\hline First grade index & Managerial ability & $\begin{array}{l}\text { resist ability to } \\
\text { environment } \\
\text { threatens }\end{array}$ & $\begin{array}{l}\text { Technological } \\
\text { ability }\end{array}$ \\
\hline$\left(U_{i}\right)$ & $\left(U_{l}\right)$ & $\left(U_{2}\right)$ & $\left(U_{3}\right)$ \\
\hline Sub grade index & $\begin{array}{l}\text { Administrator's } \\
\text { ethical quality }\end{array}$ & $\begin{array}{l}\text { National political } \\
\text { economic } \\
\text { environment }\end{array}$ & $\begin{array}{l}\text { substitutability of } \\
\text { Technology }\end{array}$ \\
\hline \multirow[t]{4}{*}{$\left(U_{i j}\right)$} & Academic level & $\begin{array}{l}\text { policies and } \\
\text { regulations }\end{array}$ & $\begin{array}{l}\text { Advancement of } \\
\text { technology }\end{array}$ \\
\hline & $\begin{array}{l}\text { Experience of } \\
\text { management }\end{array}$ & $\begin{array}{l}\text { Change of the bank } \\
\text { rate }\end{array}$ & $\begin{array}{l}\text { Suitability of } \\
\text { technology }\end{array}$ \\
\hline & $\begin{array}{l}\text { Ability of } \\
\text { association }\end{array}$ & $\begin{array}{l}\text { Investor's income of } \\
\text { the market }\end{array}$ & $\begin{array}{l}\text { Dependability of } \\
\text { technology }\end{array}$ \\
\hline & $\begin{array}{l}\text { Environmental } \\
\text { adaptive capacity }\end{array}$ & Potential rival & $\begin{array}{l}\text { Intellectual property } \\
\text { right }\end{array}$ \\
\hline
\end{tabular}




\begin{tabular}{|c|c|c|c|}
\hline \multicolumn{4}{|c|}{ Forewarning Index Systems of the Venture Enterprise $(U)$} \\
\hline First grade index & Market risk & Production risk & $\begin{array}{l}\text { Withdrawing } \\
\text { channel }\end{array}$ \\
\hline$\left(U_{i}\right)$ & $\left(U_{f}\right)$ & $\left(U_{5}\right)$ & $\left(U_{\sigma}\right)$ \\
\hline \multirow{5}{*}{$\begin{array}{l}\text { Sub grade index } \\
\left(U_{i j}\right)\end{array}$} & Market & Return on net assets & IPO \\
\hline & Market scale & $\begin{array}{l}\text { equipment } \\
\text { utilization degree }\end{array}$ & the way of Selling \\
\hline & $\begin{array}{l}\text { products } \\
\text { competence }\end{array}$ & Producer's state & $\begin{array}{l}\text { the way of } \\
\text { Withdrawing }\end{array}$ \\
\hline & Service level & Materials supplies & Liquidating \\
\hline & Marketing ability & $\begin{array}{l}\text { Additional } \\
\text { investment }\end{array}$ & $\begin{array}{l}\text { Payback period of } \\
\text { investment }\end{array}$ \\
\hline
\end{tabular}

\section{APPLYING ARTIFICIAL NEURAL NETWORK (ANN) TO FORECAST THE RISK LEVEL}

\subsection{Basic principle of BP neural network}

Figure. 1 shows a three layer BP neural topological network. Little circle means neuron unit, and the line connecting each neuron units means weight coefficient $W$. The neural network imports $X$, and exports $Y$ after the weight coefficient $W$ is dealt with. According to certain algorithm, ANN confirms the right weight coefficient $W$ of each line through studying sample data. After right weight coefficient $W$ is confirmed and the structure is steady, ANN can deal with the new data $[5,7,8,6,10]$.

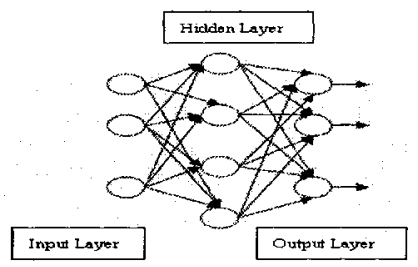

Figure 1. ANN structure

\subsection{BP ANN forewarning models}

(1) Input and Output. This article uses all sub index as input vector quantity $\mathrm{X}=\left(u_{11}, u_{12}, u_{12}, \ldots, u_{64} u_{65}\right)$, and regards forewarning risk grade as output value $Y$. Input vector quantity includes quantitative and qualitative index. Qualitative index ought to be converted to quantitative index by that experts give grade on them. This article uses interval law to define 
forewarning risk grade according to corresponding interval as table. 2 shows. $\mathrm{C}$ is the highest forewarning risk grade; AAA is the lowest forewarning risk grade.

(2) Neural network structure. There aren't perfect methods to confirm the number of neuron units of hidden layer at present, so this article adopts experience rule. If the study samples is $\mathrm{N}$, the number of neurons unit of hidden layer is $(2 \sqrt{n})$ [5]. In this way, the basic structure of the three layers ANN network is a type of 30-12-1 BP ANN.

(3) Neuron network function, error function and studying algorithm. Input layer neuron network function is $f(x)=X$, Function of hidden layer and output layer is Sigmoid function: $f(x)=1 /(1+\exp (-x))$. Initialization of all the neuron units is 0 . Weight coefficient $w_{k k}=\left(w_{i j}^{k}\right)_{n_{k-1} \quad k}$, among them, $n_{k}$ means the number of neuron units of layer $\mathrm{k}$, while $w_{i j}$ means weight coefficient between neuron unit $i$ of layer $k-1$ and neuron unit $j$ of layer $\mathrm{k}$. The receiving value of neuron unit of layer $\mathrm{k}$ is $t_{j k}=\sum_{i}^{n_{k-1}} w_{i j} x_{i}, \mathrm{j}$ $=1,2, \ldots, \mathrm{n}_{\mathrm{k}}$. The output value from layer $\mathrm{k}$ to layer $\mathrm{k}+1$ is $y_{j}=\mathrm{f}\left(\mathrm{t}_{\mathrm{ij}}\right)$, $\mathrm{j}=1,2, \ldots, \mathrm{n}_{\mathrm{k}}$. Error function is $E=\frac{1}{2} \sum_{l}^{n}\left|y_{k}-\hat{y}_{k}\right|^{2}$, among them, $\mathrm{y}_{\mathrm{k}}$ is the expected output of layer $\mathrm{k}, \hat{y}_{k}$ is the actual output of layer $\mathrm{k}$.

Table 2. Forewarning risk grade

\begin{tabular}{lllll}
\hline $\mathrm{C}$ & $\mathrm{CC}$ & $\mathrm{CCC}$ & $\mathrm{B}$ & $\mathrm{BB}$ \\
\hline$(0,0.1]$ & $(0.1,0.2]$ & $(0.2,0.3]$ & $(0.3,0.4]$ & $(0.4,0.5]$ \\
\hline $\mathrm{BBB}$ & $\mathrm{A}$ & $\mathrm{AA}$ & $\mathrm{AAA}$ & \\
\hline$(0.5,0.6]$ & $(0.6,0.7]$ & $(0.7,0.8]$ & $(0.8,0.9]$ & \\
\hline
\end{tabular}

\subsection{Empiric analysis}

The research object is 43 venture capital projects. At first, Initialize vector $X$ of each venture capital project to gain the importing vector group $X_{i}, \mathrm{i}=1,2, \ldots, 43$. Then refer to table. 2 and through expert's giving grade of 43 venture capital projects, get the expect exporting vector group $Y_{i}$, $\mathrm{i}=1,2, \ldots, 43$. Use $\left(X_{i}, Y_{i}\right)$ as the study samples, among them, $\mathrm{i}=1,2, \ldots, 40$. Use $\left(X_{j}, Y_{j}\right)$ as the evaluation target, among them $\mathrm{j}=41,42,43$. The purpose of the experiment is to compare the output evaluation result of ANN with the expert's evaluation conclusion, proving ANN risk evaluation is valid on venture capital. 
The structure of ANN is $30-12-1$ according to the order of input layer, hidden layer and output layer. Initialization value of each neuron unit is random in $[0,1]$.Study precision $\varepsilon=0$. 005. The increment coefficient of excellent fast algorithm of dropping and seeking $\eta=0.5$. In order to prove the ANN risk evaluation model is valid, I have done the experiment for 10 times, contrasting expected output value $Y_{41}=0.75, Y_{42}=0.55, Y_{43}=0.25$ (Forewarning risk grade is $\mathrm{AA}, \mathrm{BBB}, \mathrm{CCC}$ ) with corresponding actual output risk value $Y_{\mathrm{j}}^{\prime}(\mathrm{j}=41,42,43)$. The experimental result is shown in Table.3, Table.4 and Tab.5.

Table 3. Contrast of network output $Y_{4,}^{\prime}$ and expected output $Y_{d I}$

\begin{tabular}{llllll}
\hline times of experiment & 1 & 2 & 3 & 4 & 5 \\
\hline network Output & 0.753 & 0.764 & 0.755 & 0.786 & 0.793 \\
expected output & 0.75 & 0.75 & 0.75 & 0.75 & 0.75 \\
Result of evaluation & AA & AA & AA & AA & AA \\
Result of expectation & AA & AA & AA & AA & AA \\
times of experiment & 6 & 7 & 8 & 9 & 10 \\
network Output & 0.731 & 0.722 & 0.684 & 0.773 & 0.729 \\
expected output & 0.75 & 0.75 & 0.75 & 0.75 & 0.75 \\
Result of evaluation & AA & AA & A & AA & AA \\
Result of expectation & AA & AA & AA & AA & AA
\end{tabular}

Table 4. Contrast of network output $Y_{42}^{\prime}$ and expectation output $Y_{42}$

\begin{tabular}{llllll}
\hline times of experiment & 1 & 2 & 3 & 4 & 5 \\
\hline network Output & 0.534 & 0.533 & 0.554 & 0.620 & 0.589 \\
expected output & 0.55 & 0.55 & 0.55 & 0.55 & 0.55 \\
Result of evaluation & BBB & BBB & BBB & A & BBB \\
Result of expectation & BBB & BBB & BBB & BBB & BBB \\
times of experiment & 6 & 7 & 8 & 9 & 10 \\
network Output & 0.528 & 0.584 & 0.509 & 0.540 & 0.558 \\
expected output & 0.55 & 0.55 & 0.55 & 0.55 & 0.55 \\
Result of evaluation & BBB & BBB & BBB & BBB & BBB \\
Result of expectation & BBB & BBB & BBB & BBB & BBB \\
\hline
\end{tabular}

Table 5. Contrast of network output $Y_{43}^{\prime}$ and expected output $Y_{43}$

\begin{tabular}{llllll}
\hline times of experiment & 1 & 2 & 3 & 4 & 5 \\
\hline network Output & 0.233 & 0.243 & 0.256 & 0.282 & 0.246 \\
expected output & 0.25 & 0.25 & 0.25 & 0.25 & 0.25 \\
Result of evaluation & CCC & CCC & CCC & CCC & CCC \\
Result of expectation & CCC & CCC & CCC & CCC & CCC \\
times of experiment & 6 & 7 & 8 & 9 & 10 \\
network Output & 0.297 & 0.311 & 0.271 & 0.245 & 0.318 \\
expected output & 0.25 & 0.25 & 0.25 & 0.25 & 0.25 \\
Result of evaluation & B & CCC & CCC & CCC & B \\
Result of expectation & CCC & CCC & CCC & CCC & CCC \\
\hline
\end{tabular}




\section{CONCLUSIONS}

Empiric analysis indicates that forewarning index risk system based on ANN could export comparatively accurate forewarning risk grade of venture capital. In this article the forewarning risk index system and ANN forewarning model are based on the visual angle of venture capital forms. The forewarning risk index system based on ANN has solved the problem of comprehensive evaluation of venture capital very well.

We should pay attention to that the study speed of neural network is influenced by the neuron unit number of each layer, neuron network function and study algorithm, etc[5]. We should apply ANN forewarning risk model according to the actual conditions. Because the research of risk evaluation system and risk evaluation method is beginning, here remain many problems to discuss thoroughly further. I hope this paper can play a role in casting a brick to attract jade.

\section{REFERENCES}

1. $\mathrm{T} T$ Tyebjee and $\mathrm{A} V$ Bruno, $\mathrm{A}$ model of venture capitalist investment activity, Management Science, 1984 (9):300-330

2. Masako Ueda, Banks versus Venture Capital: Project Evaluation, Screening, and Expropriation, Journal of finance, 2004(4): 604-621

3. Vance $H$ Fried and Robert D Hisrich, Toward a model of venture capital investment decision making, Financial Management, 1994 (3):212-230

4. Alex Proimos, Sue Wright, A pilot study of venture capital investment appraisal in Australia, Journal of Financial Services Marketing, 2005(9):272 - 286

5. Narendra K S, Parthasarathy K, Identification and control of dynamical systems using neural network, IEEE Trans Neural Networks ,1999(1):4--27.

6. Mohamed Attalla and Tarek Hegazy, Predicting Cost Deviation in Reconstruction Projects: Artificial Neural Networks versus Regression, Journal of construction engineering and management, 2003(5): 405-510

7. Patrick L. Brockett, William W. Cooper, Linda L. Golden, Utai Pitaktong, A Neural Network Method for Obtaining an Early Warning of Insurer Insolvency, The Journal of Risk and Insurance, 1994(3): 402-424

8. Bart Baesens, et al, Using Neural Network Rule Extraction and Decision Tables for CreditRisk Evaluation, Management Science, 2003 (5): 312-329

9. Kuldeep Kumar, John D Haynes, Forecasting credit ratings using an ann and statistical techniques, International journal of business studies, 2003(6): 91-108

10. Dariusz Skorupka, Neural Networks in the Risk Management of a Project, 2004 AACE International Transactions[C], RISK.15 